\title{
ЕФЕКТИВНІСТЬ ІНДЕКСНОЇ СЕЛЕКЦІЇ У СТАДІ СИМЕНТАЛЬСЬКОЇ ПОРОДИ ЗА ОРГАНІЧНОГО ВИРОБНИЦТВА МОЛОКА
}

\author{
Кочук-Ященко Олександр Анатолійович \\ кандидат сільськогосподарських наук \\ Поліський національний університет \\ ORCID: 0000-0001-5794-5580 \\ E-mail: o.kochukyashchenko@gmail.com
}

Кучер Дмитро Миколайович кандидат сільськогосподарських наук Поліський національний університет ORCID: 0000-0002-1998-6290 E-mail: dkucher@i.ua

Шапран Інна Валентинівна магістрантка Поліський національний університет E-mail: shapraninna1998@gmail.com

\section{Мосійчук Микола Васильович} магістрант Поліський національний університет E-mail: kolya14411@gmail.com

У статті висвітлені результати відбору корів симентальської породи за вим'я-масо-метричним індексом, який є достатньо надійним і ефрективним методом для визначення кращих тварин за масо-метричними параметрами конкретного стада. Корови-первістки симентальської породи, диференційовані за величиною даного індексу, у переважній більшості випадків вірогідно відрізняються між собою за даними показниками. В иілому крупність тварин за основними промірами будови тіла у поєднанні із великою живою масою у межах груп свідчить про фрормування молочного типу екстер'єру корів-первісток симентальської породи чеської селекції ПП «Галекс-Агро». Доведено, що із підвищенням значення вим'я-масо-метричного індексу у корів відмічається статистично значуща закономірність зростання переважної більшості масо-метричних показників екстер'єру, окрім живої маси та обхвату грудей, де кращими виявилися тварини із середнім значенням екстер'єрного індексу. Загалом, за усіма показниками екстер'єру тварини із середнім та високим значенням даного індексу достовірно переважали ровесниць із низьким значенням. Відхилення від молочного типу у бік подвійної продуктивності спостерігалося за індексом формату, який визначається, як співвідношення навкісної довжини тулуба до висоти у холці. Значення даного індексу варіювало у межах груп від 126,0 до 127,2 \%. Лише за даним індексом спостерігалась статистично значуща різниця на користь тварин із високим значенням вим'я-масо-метричного індексу $(P<0,05)$. 3i збільшенням значення екстер'єрного індексу з 10,5 до 23,6 у корів відмічається подовження тривалості лактації на 29,8 днів, збільшення рівня надою за 305 днів лактації на 607 ке, отримано більшу кількість продукції молочного жиру та білка - на 21,3 та 21,7 відповідно, що підтверджено статистично значущою різницею між груповими середніми. Спостерігається математично підтверджений обернений зв'язок погіршення відтворення із зростанням вим'я-масо-метричного індексу у корів. Найкращими показниками відтворення відзначилися тварини з низьким його значенням, найгіршими - із високим. Найбільша сила впливу екстер'єрного індексу спостерігалась на морфологічні властивості вим'я (16,8\%), а найменша - на відтворну здатність (1,2). Загалом узагальнена середня сила впливу вим'я-масо-метричного індексу на всі блоки досліджуваних ознак становила 6,5 \% і у 47\% випадків із загального числа ознак виявилась вірогідною $(P<0,05-$ 0,001).

Ключові слова: симентальська порода, органічне виробництво, екстер'єр, проміри тіла, індекси, вим'я, сила впливу.

DOI: https://doi.org/10.32845/bsnau.Ivst.2020.2.8.

Молочному скотарству приділяється значна увагу в усьому світі і в Україні зокрема. Однією із основних цілей селекціонерів зі всього світу $є$ створення тварин бажаного типу з високою племінною цінністю, які б гармонійно поєднували гарний розвиток екстер'єру із здоров'ям та високорентабельне виробництво тваринницької продукції при тривалому використанні їх в тих чи інших природних і господарських умовах [1].

За останні роки дещо змінилися основні пріоритети у Вісник Сумського національного аграрного університету селекції тварин. Селекція лише за ознаками молочної продуктивності (надоєм, вмістом жиру та білка у молоці) вже є недостатньою і не в тренді у світі. Тому поряд із відбором за продуктивними якостями, проводиться відбір за плодючістю, тривалістю господарського використання, резистентністю до різних захворювань. Корови високопродуктивних стад повинні відповідати вимогам селекціонера одночасно за екстер'єром, продуктивністю та іншими господарськими ознаками [2]. 
Ефективність селекції детермінована багатьма факторами, проте головним залишається рівень точності оцінки генотипу тварин. Відчутних селекційних результатів можна досягти лише за комплексною оцінкою генотипу. Кількість ознак, які включені до такої оцінки значно збільшилась. Це зумовило перехід на індексну систему оцінки і відбору тварин як в Україні, так і за кордоном. У міжнародній практиці розрахунок індексів племінної цінності тварини може здійснюватися за 17-18 селекційними і 4-6 економічними показниками $[3,4,5]$.

Використання індексної селекції, яка виражає математично загальну племінну цінність тварин за великою кількістю ознак, у процесі створення і подальшого удосконалення голштинської худоби, зумовило вражаючі позитивні результати в Ізраїлі, США, Канаді, Німеччині, Голландії та в інших країнах світу $[4,6,7]$.

У структуру селекційних індексів тварин у країнах з високим рівнем ведення молочного скотарства, крім ознак молочної продуктивності, екстер'єру обов'язково враховують якість вим'я і його здоров'я, стан кінцівок, тривалість господарського використання та ряд інших ознак, що у комплексі дає можливість проводити ранжування тварин і відбір їх для племінного ядра стада [8]. Тому, особливу увагу заслуговують дослідження І.П. Петренка [1], який розробив та апробував в молочному стаді симентальської породи німецької селекції екстер'єрні індекси (ОТВІ і ВMМI), які достатньо істотно корелюють з показниками молочної продуктивності (від +0,35 до $+0,44)$ і включають низку масо-метричних показників тіла та проміри вим'я, що свідчить про можливість застосовувати їх в селекційній практиці з молочними та комбінованими породами корів з метою подальшої консолідації бажаного типу їх екстер'єру [1]. Дані індекси були вже апробовані нами на стаді корів української чорно-рябої молочної породи ПАФ «Єрчики» Попільнянського району Житомирської області і було доведена доцільність їх використання для покращення ознак екстер'єру і підвищення молочної продуктивності $[9,10]$. Однак ефективність кожного селекційного прийому необхідно перевіряти в умовах конкретного господарства і на різних породах.

Враховуючи вище зазначене, метою наших досліджень $€$ вивчення ефективності відбору корів-первісток за вим'я-масо-метричним індексом на покращення ознак екстер'єру і продуктивності у стаді симентальської породи за органічного виробництва молока в умовах ПП «ГалексАгро».

Матеріали та методи досліджень. Дослідження проведені на 169 коровах-первістках симентальської породи ПП «Галекс-Агро» Новоград-Волинського району Житомирської області за матеріалами племінного обліку та результатами власних досліджень.

Диференціацію корів за величиною вим'я-масометричного індексу здійснювали за методикою А. П. Полковниковой [11]. При цьому виділяли 3 групи корів у співвідношенні близько 1:2:1, що відповідає закономірностям нормального розподілу особин. До III групи (більше 19,9 у.о. BMMI) віднесені корови, які переважали середнє значення індексу на 0,7 $\sigma(>\mathrm{M}+0,7 \sigma)$, до I - поступалися на 0,7 $\sigma$ (меньше 12,3 у.о.), до II (12,3-19,9 у.о.) - знаходилися у межах $\mathrm{M} \pm 0,7 \sigma$. Групи умовно назвали низький, середній та високий.

Особливості екстер'єру та конституції тварин досліджували на 2-3 місяцях лактації за загальноприйнятими методиками.

Морфолого-функціональні показники вим'я корівпервісток оцінено на 2-3 місяці лактації, за годину до доїння, шляхом огляду та вимірювання. За промірами вим'я обчислено вим'я-масо-метричний індекс (BMMI), який виражається в умовних одиницях (за І. П. Петренком зі співав. [12]):

$$
\mathrm{BMMI}=\frac{\mathrm{OB} \times Ж \mathrm{M}}{\mathrm{BX}+\mathrm{KДT}+\mathrm{O} \Gamma}
$$

де ОВ - об'єм вим'я, дм³; ЖМ - жива маса, кг; ВX висота в холці, см; КДТ - навкісна довжина тулуба, см; ОГ обхват грудей, см.

Оцінку молочної продуктивності корів здійснювали шляхом проведення щомісячного контрольного доїння 3 одночасним визначенням у добових зразках молока вмісту жиру. Відносну молочність обчислювали діленням 4\%-го за вмістом жиру молока, отриманого за 305 днів або скорочену лактацію (не менше 240 днів) на 100 кг живої маси корови.

Відтворну здатність корів вивчали за віком 1-го отелення (міс), тривалістю (днів) сервіс-періоду (СП), періоду тільності (ПТ), міжотельного періоду (МОП), періоду сухостою (ПС) та за коефріцієнтом відтворної здатності (КВЗ).

Коефіцієнт фенотипової консолідації ознак лінійної класифікації екстер'єрного типу $\left(K_{1}, K_{2}\right)$ та їх середнього значення ( $\mathrm{K}_{\text {ср.) }}$ обчислювали за формулами Ю. П. Полупана [13].

Ступінь впливу екстер'єрного індексу на досліджувані ознаки вираховували відношенням факторіальної дисперсії до загальної в однофракторному дисперсійному комплексі.

Статистична обробка результатів проводилась з використанням пакету аналізу Microsoft Excel.

Результати досліджень. Селекційно-племінна робота у молочному скотарстві сфрокусована на формуванні високопродуктивних стад різних порід, які характеризуються доброю придатністю до використання в умовах високомеханізованих комплексів впродовж тривалого терміну їх життя. Тільки фізично здорові, з гарним екстер'єрно-конституційним типом тварини здатні до високої продуктивності у сучасних умовах. Тобто, екстер'єрний тип, як інтегральна ознака організму спадково обумовлена і формується в онтогенезі у результаті загальновідомої взаємодії «генотип-середовище» [14-15].

Досить повне уявлення про екстер'єрний тип, типовість, напрям продуктивності тварин можна отримати шляхом проведення оцінки екстер'єру взяттям промірів окремих статей тіла та зважуванням. Інструментальна оцінка екстер'єру тварин $€$ обов'язковою компонентою для оцінки племінної цінності тварин.

Тому нами було вивчено масо-метричні параметри тулуба корів-первісток симентальської породи залежно від величини вим'я-масо-метричного індексу (табл. 1).

Одержані нами дані переконливо свідчать, що використання вим'я-масо-метричного індексу при розподілі тварин на групи $є$ достатньо надійним і ефективним методом для визначення кращих груп тварин за масо-метричними параметрами у стаді ПП «Галекс-Агро». Корови-первістки симентальської породи, диференційовані за величиною даного індексу, у переважній більшості випадків вірогідно відрізняються між собою за даними показниками. В цілому крупність тварин за основними промірами будови тіла у поєднанні із великою живою масою у межах груп свідчить про фрормування молочного типу екстер'єру корів-первісток симентальської породи чеської селекції ПП «Галекс-Агро».

Вісник Сумського національного аграрного університету 
Масо-метричні показники екстер'єру корів-первісток симентальської породи залежно від величини екстер'єрного індексу

\begin{tabular}{|c|c|c|c|c|c|}
\hline \multirow{3}{*}{ Показники, одиниці виміру } & \multicolumn{3}{|c|}{ Групи корів за екстер'єрним індексом } & \multirow{2}{*}{\multicolumn{2}{|c|}{$\begin{array}{c}\text { Різниця |-III } \\
\text { v }=81\end{array}$}} \\
\hline & $\begin{array}{c}\text { I- низький } \\
(n=43)\end{array}$ & $\begin{array}{c}\text { II-середній } \\
(\mathrm{n}=86)\end{array}$ & $\begin{array}{c}\text { III-високий } \\
(\mathrm{n}=40)\end{array}$ & & \\
\hline & X \pm S.E. & X \pm S.E. & $\mathrm{X} \pm$ S.E. & $d \pm S . D$. & $\mathrm{td}$ \\
\hline Жива маса, кг & $586,7 \pm 7,86$ & $628,1 \pm 5,11$ & $625,4 \pm 8,31$ & $-38,7 \pm 11,44$ & $3,38^{2}$ \\
\hline $\begin{array}{l}\text { Проміри, см: } \\
\text { висота в холці }\end{array}$ & $133,7 \pm 0,35$ & $135,7 \pm 0,33$ & $135,8 \pm 0,44$ & $-2,1 \pm 0,56$ & $3,67^{3}$ \\
\hline висота в крижах & $140,6 \pm 0,45$ & $142,4 \pm 0,37$ & $142,6 \pm 0,54$ & $-2,0 \pm 0,71$ & $2,79^{2}$ \\
\hline глибина грудей & $72,8 \pm 0,31$ & $73,8 \pm 0,22$ & $74,2 \pm 0,30$ & $-1,3 \pm 0,43$ & $3,12^{2}$ \\
\hline ширина грудей & $49,8 \pm 0,28$ & $50,8 \pm 0,23$ & $51,6 \pm 0,35$ & $-1,8 \pm 0,45$ & $3,97^{3}$ \\
\hline довжина грудей & $78,8 \pm 0,41$ & $80,6 \pm 0,24$ & $81,4 \pm 0,52$ & $-2,6 \pm 0,66$ & $3,97^{3}$ \\
\hline обхват грудей & $200,8 \pm 1,13$ & $205,8 \pm 0,63$ & $205,5 \pm 1,07$ & $-4,7 \pm 1,55$ & $3,02^{2}$ \\
\hline навскісна довжина тулубу & $168,4 \pm 0,77$ & $172,5 \pm 0,49$ & $172,6 \pm 0,74$ & $-4,1 \pm 1,07$ & $3,87^{3}$ \\
\hline ширина в маклоках & $50,5 \pm 0,20$ & $51,6 \pm 0,16$ & $52,1 \pm 0,35$ & $-1,6 \pm 0,40$ & $3,99^{3}$ \\
\hline ширина в сідничних горбах & $31,5 \pm 0,27$ & $32,8 \pm 0,17$ & $33,6 \pm 0,35$ & $-2,1 \pm 0,44$ & $4,68^{3}$ \\
\hline обхват п'ястка & $19,1 \pm 0,15$ & $19,6 \pm 0,12$ & $19,6 \pm 0,20$ & $-0,5 \pm 0,25$ & $2,05^{1}$ \\
\hline
\end{tabular}

Було встановлено, що із підвищенням значення вим'я-масо-метричного індексу у корів відмічається статистично значуща закономірність зростання переважної більшості масо-метричних показників екстер'єру, окрім живої маси та обхвату грудей, де кращими виявилися тварини ॥ групи, з середнім значенням екстер'єрного індексу. Однак статистично значущої різниці між тваринами II і III груп за цими показниками не спостерігалось. Загалом тварини даних груп у 100\% випадків вірогідно переважали ровесниць І групи (P<0,05-0,001).

Найкращим молочним типом, який виражений розвитком будови тіла характеризуються тварини III групи із найвищим значенням вим'я-масо-метричного індексу. Коровипервістки симентальської породи даної групи відзначилися великою живою масою - 625,4 кг, що на 38,7 кг вірогідно більше у порівнянні із тваринами I групи; високорослістю 135,8 і 142,6 см у холці і крижах відповідно, що на 2,1 і 2,0 см більше; достатнім розвитком грудей: ширина - 51,6, глибина 74,2, обхват - 205,5 cм, що на 1,8; 1,3 та 4,7 см більше; довгим тулубом - 172,6 см навскісна довжина тулуба; широким задом - 52,1 і 33,6 см у маклоках та сідничним горбах; рівною спиною та попереком із міцними кінцівками $(\mathrm{P}<0,01-0,001)$. Суттєвих закономірностей за значенням коефіцієнта мінливості у межах досліджуваних груп не спос- терігалось.

Отже, результати досліджень у стаді симентальської породи ПП «Галекс-Агро» ще раз доводять можливість есрективного використання даного індексу в системі селекції корів для внутрішньої диференціації стада за екстер'єрним типом та відбором кращих тварин для подальшого розведення та удосконалення високопродуктивного стада тварин із гарним здоров'ям.

Важливим матеріалом для об'єктивної оцінки тварин за екстер'єрним типом, поряд із промірами, є й індекси будови тіла, які вирахувані через співвідношення анатомоморфологічно пов'язаних між собою статей екстер'єру. Саме індекси будови тіла дозволяють селекціонерам визначити тип конституції, індивідуальні особливості, ступінь та пропорційність розвитку організму, вікову мінливість, кондиції та продуктивність тварин у конкретних господарських умовах [16].

Індекси будови тіла корів-первісток різних дослідних груп, диференційованих за вим'я-масо-метричним індексом, засвідчують формування молочного типу екстер'єру корів і ще раз підтверджують гармонійний, пропорційний розвиток усіх статей тіла тварин не залежно від групи. Суттєвих закономірностей і тенденцій із підвищенням вим'я-масометричного індексу не вдалося встановити (табл. 2).

Таблиця 2

Індекси будови тіла корів-первісток симентальської породи залежно від величини екстер'єрного індексу

\begin{tabular}{|c|c|c|c|c|c|}
\hline \multirow{3}{*}{ Показники, одиниці виміру } & \multicolumn{3}{|c|}{ Групи корів за екстер'єрним індексом } & \multirow{2}{*}{\multicolumn{2}{|c|}{$\begin{array}{c}\text { Різниця I-III } \\
\text { V =81 }\end{array}$}} \\
\hline & $\begin{array}{c}\text { I- низький } \\
(\mathrm{n}=43)\end{array}$ & $\begin{array}{c}\text { II-середній } \\
(\mathrm{n}=86)\end{array}$ & $\begin{array}{c}\text { III-високий } \\
(\mathrm{n}=40)\end{array}$ & & \\
\hline & $X \pm S . E$. & $X \pm S . E$. & $X \pm S . E$. & $\mathrm{d} \pm$ S.D. & td \\
\hline Довгоногості & $45,5 \pm 0,27$ & $45,6 \pm 0,13$ & $45,3 \pm 0,24$ & $+0,2 \pm 0,36$ & 0,45 \\
\hline Формату & $126,0 \pm 0,47$ & $127,1 \pm 0,29$ & $127,2 \pm 0,56$ & $-1,2 \pm 0,73$ & 1,59 \\
\hline Компактності & $119,2 \pm 0,50$ & $119,3 \pm 0,27$ & $119,1 \pm 0,48$ & $+0,1 \pm 0,69$ & 0,20 \\
\hline Масивності & $150,2 \pm 0,77$ & $151,6 \pm 0,31$ & $151,4 \pm 0,79$ & $-1,2 \pm 1,10$ & 1,10 \\
\hline Костистості & $14,3 \pm 0,11$ & $14,4 \pm 0,08$ & $14,4 \pm 0,14$ & $-0,2 \pm 0,18$ & 0,87 \\
\hline
\end{tabular}

Варто відмітити, що відхилення від молочного типу у бік подвійної продуктивності спостерігався за індексом формату, який визначається, як співвідношення навкісної довжини тулуба до висоти у холці. Значення даного індексу варіювало у межах груп від 126,0 до 127,2%. Лише за даним індексом спостерігалась статистично значуща різниця на користь тварин III-ї порівняно із І-ю групою $(\mathrm{P}<0,05)$.

Вим'я - це найважливіша ознака екстер'єру молочної худоби, яка оцінюється за його будовою та структурою. Параметри вим'я спричиняють суттєвий вплив на: рівень надоїв, пристосованість до машинного доїння, травмування та інфікування вим'я. Вим'я корів, які розводяться на сучасних молочних комплексах повинно характеризуватися відповідними параметрами [17-19].

У ПП «Галекс-Агро» доїння проводиться у доїльному залі, тому закордонними спеціалістами, які проводять кон-

Вісник Сумського національного аграрного університету 
сультування, складання плану підбору, особлива увага надається такому важливому питанню, як селекція за параметрами вим'я та підбору препотентних бугаїв, оскільки від цього напряму залежить рівень рентабельності господарства.

У зв'язку із вищезазначеним, у своїх дослідженнях ми проаналізували вплив вим'я-масо-метричного індексу на морфологічні властивості вим'я корів симентальської породи чеської селекції (табл. 3). Виявлено істотний рівень міжгрупової диференціації за переважною більшістю показників морфологічних властивостей вим'я корів різних груп, диференційованих за вим'я-масо-метричним індексом. Це $є$ цілком закономірним, оскільки даний екстер'єрний індекс, крім живої маси та низки традиційних лінійних промірів будови тіла, також включає об'єм вим'я. Це все у сукупності дає можливість з більшою точністю прогнозувати рівень молочної продуктивності корів і проводити непряму селекцію за даним індексом. Також, як і за промірами будови тіла, так і за морфологічними властивостями вим'я, спостерігається стале вірогідне збільшення практично за всіма досліджуваними ознаками вим'я корів досліджуваного стада із зростанням вим'я-масо-метричного індексу. Тобто корови стають більш пристосованими до машинного доїння на сучасному комплексі. Виключенням із загальної закономірності $є$ криволінійна зміна таких морфологічних ознак, як відстань від дна вим'я до землі та діаметр задніх дійок, що можна пояснити, на нашу думку, невеликою чисельністю вибірки у межах досліджуваних груп.

Таблиця 3

Морфологічні властивості вим'я корів-первісток симентальської породи залежно від величини екстер'єрного індексу

\begin{tabular}{|c|c|c|c|c|c|}
\hline \multirow{3}{*}{ Показник, одиниці виміру } & \multicolumn{3}{|c|}{ Групи корів за екстер'єрним індексом } & \multirow{2}{*}{\multicolumn{2}{|c|}{$\begin{array}{c}\text { Різниця I-III } \\
\text { v=81 }\end{array}$}} \\
\hline & \multirow{2}{*}{$\begin{array}{c}\begin{array}{c}\mathrm{I}-\text { низький } \\
(\mathrm{n}=43)\end{array} \\
\mathrm{X} \pm \mathrm{S} . \mathrm{E} . \\
\end{array}$} & \multirow{2}{*}{$\begin{array}{c}\begin{array}{c}\text { II-середній } \\
(\mathrm{n}=86)\end{array} \\
\mathrm{X} \pm \text { S.E. } \\
\end{array}$} & \multirow{2}{*}{$\begin{array}{c}\begin{array}{c}\text { III-високий } \\
(\mathrm{n}=40)\end{array} \\
\mathrm{X} \pm \mathrm{S} . \mathrm{E} . \\
\end{array}$} & & \\
\hline & & & & $\mathrm{d} \pm \mathrm{S}$.D. & td \\
\hline Обхват вим'я, см & $115,0 \pm 1,23$ & $119,9 \pm 0,69$ & $129,1 \pm 1,12$ & $-14,2 \pm 1,67$ & $8,50^{3}$ \\
\hline Довжина вим'я, см & $35,7 \pm 0,56$ & $39,2 \pm 0,43$ & $46,2 \pm 0,69$ & $-10,5 \pm 0,89$ & $11,77^{3}$ \\
\hline Ширина вим'я, см & $26,4 \pm 0,39$ & $30,5 \pm 0,31$ & $34,8 \pm 0,44$ & $-8,4 \pm 0,59$ & $14,23^{3}$ \\
\hline Глибина вим'я, см & $27,2 \pm 0,42$ & $30,1 \pm 0,34$ & $34,2 \pm 0,56$ & $-7,0 \pm 0,70$ & $9,97^{3}$ \\
\hline Відстань від дна вим'я до землі, см & $59,1 \pm 0,77$ & $59,0 \pm 0,59$ & $56,5 \pm 0,85$ & $2,6 \pm 1,15$ & $2,26^{1}$ \\
\hline Довжина передніх дійок, см & $6,0 \pm 0,20$ & $6,3 \pm 0,14$ & $6,8 \pm 0,27$ & $-0,7 \pm 0,34$ & $2,16^{1}$ \\
\hline Довжина задніх дійок, см & $5,1 \pm 0,22$ & $5,3 \pm 0,15$ & $5,7 \pm 0,23$ & $-0,6 \pm 0,32$ & $2,00^{1}$ \\
\hline Відстань між передніми дійкам, см & $14,5 \pm 0,44$ & $16,2 \pm 0,39$ & $16,4 \pm 0,60$ & $-1,9 \pm 0,75$ & $2,52^{1}$ \\
\hline Відстань між задніми дійками, см & $8,3 \pm 0,40$ & $8,2 \pm 0,26$ & $9,3 \pm 0,48$ & $-1,0 \pm 0,63$ & 1,53 \\
\hline Відстань між боковими дійками, см & $12,6 \pm 0,39$ & $14,4 \pm 0,32$ & $14,4 \pm 0,56$ & $-1,9 \pm 0,69$ & $2,72^{2}$ \\
\hline Діаметр передніх дійок, мм & $2,2 \pm 0,03$ & $2,2 \pm 0,02$ & $2,3 \pm 0,03$ & $-0,1 \pm 0,04$ & $3,19^{2}$ \\
\hline Діаметр задніх дійок, мм & $2,3 \pm 0,02$ & $2,2 \pm 0,02$ & $2,9 \pm 0,09$ & $-0,6 \pm 0,49$ & 1,26 \\
\hline
\end{tabular}

Зокрема обхват вим'я зріс від 115,0 до 129,1 см; довжина - 35,7-46,2; ширина - 26,4 і 34,8 см; глибина 27,2

- 34,2; довжина передніх та за задніх дійок - відповідно порівнянь у 10 випадках виявилась вірогідною ( $P<0,05-0,001)$, що становить $84 \%$. Узагальнюючий критерій достовірності Стьюдента між групами становив: I-II - 2,60, IIII - 5,12; II-III - 3,52

Отримані результати досліджень також підтвердили можливість ефективного використання даного індексу для відбору корів та селекції на покращення ознак вим'я і, як результат, збільшення молочної продуктивності.

Основною метою і головним напрямом селекції молочної худоби є підвищення кількості молока високої якості і збільшення тривалості її господарського використання у
6,0-6,8 та 5,1-5,7; відстань між передніми дійками - 14,516,4 см. Максимальна різниця спостерігалася між крайніми групами, яка

iз 12 сучасних умовах виробництва. Тому, саме рівень рентабельності галузі молочного скотарства визначається показниками молочної продуктивності корів. Саме молочна продуктивність є основним показником ефективності застосування того чи іншого селекційного прийому і визначає конкурентоздатність молочних стад, порід великої рогатої худоби $[9,20$, 21].

За результатами досліджень встановлено, що в однакових умовах годівлі, утримання і доїння тварини всіх груп характеризуються високою молочною продуктивністю (табл. 4).

Таблиця 4

Молочна продуктивність корів-первісток симентальської породи залежно від величини екстер'єрного індексу

\begin{tabular}{|c|c|c|c|c|c|}
\hline \multirow{3}{*}{ Показники, одиниці виміру } & \multicolumn{3}{|c|}{ Групи корів за екстер'єрним індексом } & \multirow{2}{*}{\multicolumn{2}{|c|}{$\begin{array}{c}\text { Різниця I-III } \\
\text { v =81 }\end{array}$}} \\
\hline & $\begin{array}{c}\text { I- низький } \\
(\mathrm{n}=43)\end{array}$ & $\begin{array}{l}\text { II-середній } \\
(\mathrm{n}=86)\end{array}$ & $\begin{array}{l}\text { III-високий } \\
(\mathrm{n}=40)\end{array}$ & & \\
\hline & $X \pm S . E$. & $X \pm S . E$. & $X \pm S . E$. & $\mathrm{d} \pm$ S.D. & $\mathrm{td}$ \\
\hline Тривалість лактації, днів & $339,2 \pm 9,64$ & $356,9 \pm 6,41$ & $369,0 \pm 9,51$ & $-29,8 \pm 13,54$ & $2,20^{1}$ \\
\hline Надій за лактацію, кг & $7496 \pm 298,9$ & $8176 \pm 225,3$ & $8759 \pm 319,85$ & $-1263 \pm 437,8$ & $2,88^{2}$ \\
\hline Надій за 305 днів, кг & $6450 \pm 170,2$ & $6885 \pm 136,5$ & $7057 \pm 166,55$ & $-607 \pm 238,2$ & $2,55^{1}$ \\
\hline Вміст жиру у молоці, \% & $4,36 \pm 0,04$ & $4,25 \pm 0,03$ & $4,27 \pm 0,05$ & $+0,08 \pm 0,06$ & 1,31 \\
\hline Молочний жир, кг & $280,0 \pm 7,05$ & $291,1 \pm 5,57$ & $301,3 \pm 7,67$ & $-21,3 \pm 10,42$ & 2,04 \\
\hline Вміст білка у молоці, \% & $3,50 \pm 0,03$ & $3,52 \pm 0,02$ & $3,50 \pm 0,04$ & $+0,00 \pm 0,05$ & 0,04 \\
\hline Молочний білок, кг & $225,2 \pm 5,90$ & $241,3 \pm 4,64$ & $246,8 \pm 6,39$ & $-21,7 \pm 8,70$ & $2,49^{1}$ \\
\hline Молочний жир і білок, кг & $505,2 \pm 12,72$ & $532,4 \pm 10,04$ & $548,1 \pm 13,66$ & $-42,9 \pm 18,67$ & $2,30^{1}$ \\
\hline Відносна молочність, кг & $1205,0 \pm 35,67$ & $1164,8 \pm 24,24$ & $1217,7 \pm 39,61$ & $-12,7 \pm 53,31$ & 0,24 \\
\hline
\end{tabular}


У результаті порівняння середніх значень ознак молочної продуктивності корів-первісток симентальської породи різних груп, диференційованих за екстер'єрним індексом, вдалося встановити суттєві міжгрупові відмінності і здійснити диференціацію груп тварин досліджуваного стада за показниками молочної продуктивності за статистично значущої міжгрупової різниці у більшості випадків.

Загалом, міжгрупова різниця за показниками молочної продуктивності виявилась статистично значущою у 9 випадках із 27, що складає 33 \% від загальної кількості пар порівнянь. Максимальна міжгрупова різниця виявилась між крайніми групами. Статистично значущої різниці на користь тварин III групи не було виявлено лише за якісними показниками молочної продуктивності. Варто відмітити, що із підвищенням вим'я-масо-метричного індексу спостерігається прямолінійне зростання кількісних ознак молочної продуктивності (надій за 305 днів і всю лактацію, молочний жир і білок) і зменшення якісних (вміст жиру і білка).

Порівняно висока фенотипова мінливість у межах всіх груп спостерігалась за надоєм за всю лактацію (23,2$26,2 \%)$ та відносною молочністю (19,3-20,6 \%). Невисокою фенотиповою мінливістю характеризуються такі ознаки, як вміст жиру (6,2-7,3 \%) та білка у молоці (5,9-7,5 \%). Загалом коефіцієнти мінливості всіх ознак молочної продуктивності були вищими у корів І-ї групи порівняно з ровесницями III-ї, що також свідчить про вищу консолідованість тварин III-ї групи порівняно із І-ю.

Отже, кращими кількісними показниками молочної продуктивності відзначилися тварини III-ї групи, найгіршими - І-ї групи, статистично значущої різниці за якісними показниками не спостерігалось. Відбір тварин за вим'я-масометричним індексом сприятиме не лише покращенню екс- тер'єру, а і значному збільшенню кількісних показників молока при несуттєвому впливі на якісні.

Відтворення корів, за останні роки, є ключовою проблемою галузі молочного скотарства в Україні та світі та важливим аспектом рівня рентабельності. Особливо проблема відтворення корів спостерігається у високопродуктивних стадах. Основними причинами погіршення відтворної здатності є: спрямована однобічна селекція на зростання надою, ембріональна смертність, висока концентрація тварин на обмежених територіях, обмежений моціон, незадовільна робота техніка штучного осіменіння. Ці несприятливі фрактори у комплексі з посиленим проявом лактаційної домінанти тягнуть за собою тривале безпліддя корів і знижують темпи відтворення молочних стад в цілому [13-17]. Регулярні отелення протягом тривалого періоду часу $є$ передумовою економічної ефективності галузі, які дають можливість більш ефективно проводити селекцію у стаді, шляхом відбору та підбору тварин.

У зв'язку з цим, дослідження окресленої проблеми є достатньо актуальним, тому нами і було досліджено вплив вим'я-масо-метричного індексу на ознаки відтворення (табл. 5).

Аналізом даних таблиці було встановлено, що із підвищенням екстер'єрного індексу спостерігається статистично значуще погіршення основних біологічних періодів відтворення. Найкращими показниками відтворення відзначилися тварини І-ї групи, найгіршими - III-ї. Тобто тварини, які характеризувалися вищою молочною продуктивність, відповідно, мали гірші показники відтворення, що ще раз підтверджує антагонізм між молочною продуктивністю та відтворною здатністю.

\begin{tabular}{|c|c|c|c|c|c|}
\hline \multirow{3}{*}{ Показники, одиниці виміру } & \multicolumn{3}{|c|}{ Групи корів за екстер'єрним індексом } & \multirow{2}{*}{\multicolumn{2}{|c|}{$\begin{array}{c}\text { Різниця I-III } \\
\text { v=81 }\end{array}$}} \\
\hline & $\begin{array}{c}\text { I- низький } \\
(\mathrm{n}=43)\end{array}$ & $\begin{array}{c}\text { II-середній } \\
(n=86)\end{array}$ & $\begin{array}{c}\text { III-високий } \\
(\mathrm{n}=40)\end{array}$ & & \\
\hline & $\mathrm{X} \pm \mathrm{S} . \mathrm{E}$. & $\mathrm{X} \pm \mathrm{S} . \mathrm{E}$. & $\mathrm{X} \pm \mathrm{S} . \mathrm{E}$. & $\mathrm{d} \pm$ S.D. & td \\
\hline Вік 1-го отелу, днів & $833,8 \pm 8,26$ & $857,0 \pm 12,95$ & $860,4 \pm 12,84$ & $-26,6 \pm 15,27$ & 1,74 \\
\hline Сервіс період, днів & $111,7 \pm 7,50$ & $128,0 \pm 5,32$ & $136,0 \pm 7,92$ & $-24,4 \pm 10,91$ & $2,23^{1}$ \\
\hline Сухостійний період, днів & $55,2 \pm 1,32$ & $54,1 \pm 1,06$ & $53,5 \pm 1,36$ & $+1,7 \pm 1,90$ & 0,90 \\
\hline Міжотельний період, днів & $391,7 \pm 8,62$ & $411,1 \pm 5,95$ & $422,0 \pm 9,03$ & $-30,4 \pm 12,49$ & $2,43^{1}$ \\
\hline Тривалість тільності, днів & $280,0 \pm 1,94$ & $283,1 \pm 1,22$ & $286,0 \pm 2,84$ & $-6,0 \pm 3,44$ & 1,75 \\
\hline Коефіцієнт відтворної здатності & $0,95 \pm 0,02$ & $0,90 \pm 0,01$ & $0,88 \pm 0,02$ & $+0,07 \pm 0,03$ & $2,48^{1}$ \\
\hline
\end{tabular}

Встановлено, що найнижчим віком першого отелення (833,8 днів), сервіс-періодом (111,7 днів), тривалістю тільності (280,0 днів), міжотельним періодом (391,7 днів) і як наслідок найкращим коефріцієнтом відтворної здатності $(0,95)$ відзначилися тварини першої групи. Найменшим сухостійним періодом характеризувалися тварини III-ї групи (53,5 днів). Загалом, різниця виявилась статистично значущою $(P<0,05)$ лише між тваринами крайніх груп за тривалістю сервіс- та міжотельного періодів, коефіцієнтом відтворної здатності, що становить $50 \%$ від загальної чисельності врахованих ознак.
Коефіцієнти фенотипової консолідованості дають можливість об'єктивно дифреренціювати різні селекційні групи тварин за даним індексом та виявити однорідність або різнорідність за досліджуваними ознаками.

Фенотиповий прояв консолідованості корів-первісток симентальської породи за ознаками екстер'єрного типу і продуктивності вивчали у динаміці зростання значення вим'я-масо-метричного індексу в межах трьох груп, для цього були обраховані коефіцієнти фенотипової консолідованості даних ознак (рис.1). 


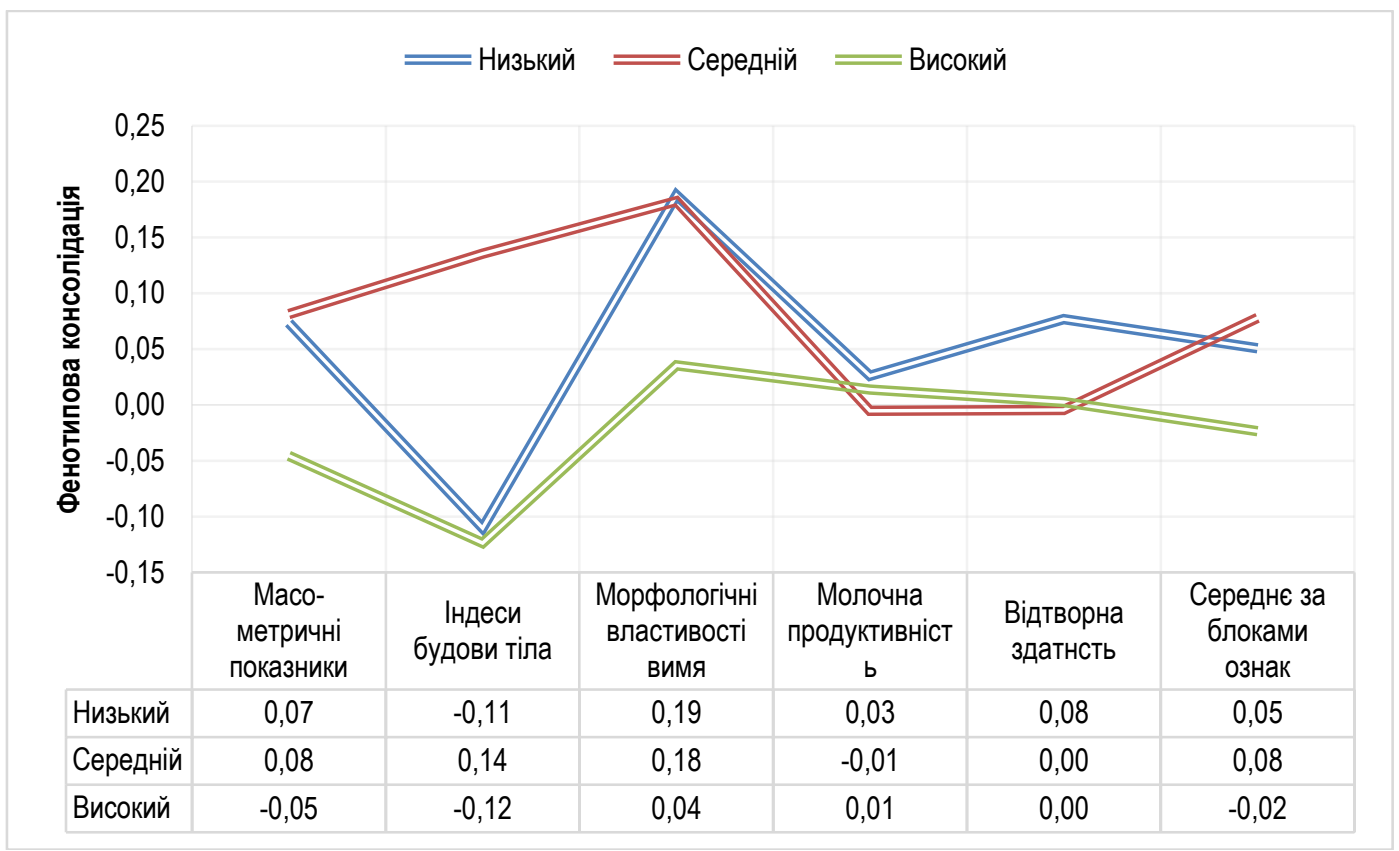

Puc. 1. Ступінь фенотипової консолідації тварин різних груп за блоками вивчених ознак

Суттєвих закономірностей у динаміці зростання значення екстер'єрного індексу не вдалося встановити. Проте, слід відмітити деякі тенденції. Зокрема, найменшою мінливістю коефіцієнтів консолідації характеризуються ознаки морфологічних властивостей вим'я та відтворної здатності, найбільшою - молочної продуктивності та індекси будови тіла. За ступенем фенотипової консолідації за всіма блоками вивчених ознак групи, диференційовані за вим'я-масометричним індексом, розмістились у такій послідовності: II група - + 0.08; I група - +0,05; III група - -0,02. Тобто, значення коефіцієнтів фенотипової консолідації тварин різних груп у середньому характеризуються як додатнім, так і від'ємним значенням при незначній мінливості. Від'ємним значенням узагальненого середнього коефіцієнта консолідації за всіма блоками ознак характеризуються тварини із найбільшим значенням вим'я-масо-метричного індексу, що свідчить про значну їх гетерозиготність у межах групи і можливість ефективної селекції на покращення досліджуваних ознак у стаді.

Результати дисперсійного аналізу, які виражені математично і підтверджені статистично, дають можливість визначити частку впливу досліджуваних чинників у загальній мінливості ознак, що вивчаються. За використання однофакторного дисперсійного аналізу підтверджено вплив екстер'єрного індексу на прояв досліджуваних комплексів ознак (рис. 2).

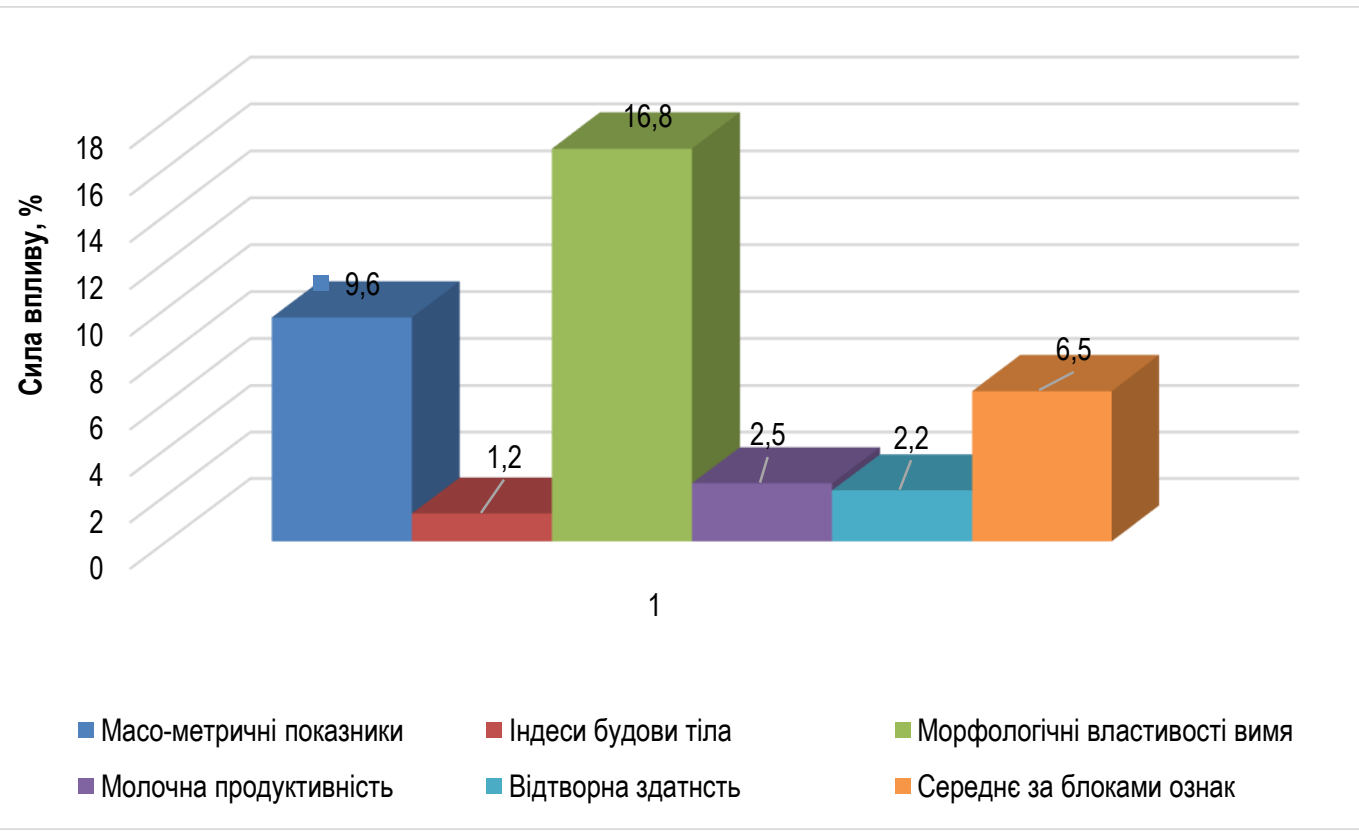

Puc. 2. Сила впливу екстер'єрного індексу на досліджувані блоки ознак

На рисунку 2 зображена узагальнена сила впливу | екстер'єрного індексу на досліджувані комплекси ознак. 
Даний рисунок яскраво ілюструє, що найбільший вплив спостерігався на морфологічні властивості вим'я (16,8\%), а найменший - на відтворну здатність $(1,2)$. Загалом узагальнена середня сила впливу вим'я-масо-метричного індексу на всі блоки досліджуваних ознак становила $6,5 \%$ і у $47 \%$ випадків із загального числа ознак виявилась достовірною $(\mathrm{P}<0,05-0,001)$.

У межах досліджуваних блоків ознак спостерігалась значна мінливість сили впливу, як за значенням, так і за вірогідністю. Зокрема, сила впливу величини вим'я-масометричного індексу у загальній частці мінливості основних промірів вим'я (обхват, довжина, ширина, глибина передньої частки вим'я) займає значний відсоток - від 34 до $53 \%$. Вплив цього фактору підтверджується статистично $(<0,001)$, тому це необхідно враховувати у подальшій селекційній роботі. Також виявлений незначний, проте статистично значущий вплив $(<0,05-<0,001)$ на розміщення та діаметр передніх сосків корів (4-8\%).

Рівень та достовірність ( $P<0,05-0,001)$ коефіцієнтів сили впливу величини вим'я-масо-метричного індексу на показники екстер'єру, а саме промірів статей тіла первісток $\left(\eta x^{2}=4,0-15,0 \%\right)$ та їх живої маси $\left(\eta x^{2}=11,0 \%\right)$, що свідчить про доцільність застосування відбору корів за даним індексом. Слід звернути увагу, що статистично-значущого впливу на індекси будови тіла з боку величини вим'я-масометричного індексу не спостерігалось.

Серед ознак молочної продуктивності виявлений статистично-значущий вплив на надій тварин за усю лактацію $(P<0,05)$. На решту ознак значного та статистично значущого впливу збоку даного екстер'єрного індексу не виявлено. Це стосується і відтворної здатності корів - сила впливу виявилась незначною (від 1 до 4 \%) та недостовірною $(P>0,05)$.

Висновки. За результатами проведених досліджень обґрунтована доцільність відбору корів симентальської породи за вим'я-масо-метричним індексом, адже виявлення і використання тварин з бажаними параметрами сприятиме покращенню їх екстер'єру, живої маси та, як наслідок призведе в подальшому підвищенню рівня молочної продуктивності, що є досить важливим у селекційному процесі поліпшення заводського стада

Із підвищенням значення вим'я-масо-метричного індексу у корів відмічається статистично значуща закономірність зростання переважної більшості масо-метричних показників екстер'єру, морфологічних властивостей вим'я, молочної продуктивності при деякому погіршенні ознак відтворної здатності.

Найбільша сила впливу екстер'єрного індексу спостерігалась на морфологічні властивості вим'я (16,8\%), а найменша - на відтворну здатність $(1,2)$. Загалом узагальнена середня сила впливу вим'я-масо-метричного індексу на всі блоки досліджуваних ознак становила 6,5 \% і у 47\% випадків із загального числа порівнянь виявилась вірогідною $(\mathrm{P}<0,05-0,001)$.

\section{Список використаної літератури:}

1.Петренко І. П., Єфріменко С. Т., Мохначова О. І., Цапко В. А. Молочна продуктивність симентальських первісток залежно від екстер'єрних типів та індексів. Розведення і генетика тварин. 2011. № 45. С. 199-206.

2.Гончаренко І. В. Селекційні індекси у системі селекції молочних корів. К.: Аграрна наука, 2007. 68 с.

3.Боднар П. В., Боднар М. Р. Використання селекційних індексів за комплексом фенотипових ознак у селекції молочної худоби та диференціації за господарським призначенням. Біологія тварин. 2015. Т. 17. № 4. С. 163

4.Гончаренко І. В. Система інформаційного забезпечення і прискорення селекційного процесу в молочному скотарстві. Збірник наукових праць ВНАУ. 2010. № 5 (45). С. 21-24.

5.Шабля В., Синицька О. Селекційний індекс пожиттєвого прибутку племінних бугаїв молочних порід. Тваринництво України № 3-4. 2014. С. 36-40.

6.Рубан С. Ю., Костенко О. І., Даншин В. О., Бакадоров П. П. Методологія оцінки змін у популяціях молочної худоби як засіб визначення стратегії їх селекційного удосконалення. Науковий вісник НУБіП України. 2009. № 138. С. $39-47$.

7. Ferguson G. Don`t blame high milk production. Western Dairy Business. 2002. № 2. P. 23-25.

8.Бабік Н. П. Тривалість та ефективність довічного використання корів голштинської породи залежно від селекційних індексів їх предків. Вісник Сумського національного аграрного університету. 2017. Вип. 5/1 (31). С. 16-21.

9.Пелехатий М. С., Кочук-Ященко О. А. Молочна продуктивність та екстер'єрний тип корів-первісток української чорно-рябої молочної породи залежно від вим'я-масо-метричного індексу. Розведення і генетика тварин. Київ. 2019. Вип. 57. С. 102-110.

10.Пелехатий М. С., Піддубна Л. М., Кучер Д. М., Кочук-Ященко О. А. Ефективність використання непрямого відбору молочних корів за масо-метричними параметрами. Агропромислове виробництво Полісся. 2018. - Вип. 11. С. 96-100.

11.Полковникова А. П. Фролов М. М., Мальцев А. С. Методические рекомендации по управлению селекционным процессом в стадах и породном массиве крупного рогатого скота. Х. : НИИЖ Лесостепи и Полесья УССР, 1987. 40 с.

12.Петренко І. П., Полупан Ю. П. Прогнозування продуктивності молочних корів. Вісник Сумського національного аграрного університету. Серія «Тваринництво». 2003. Вип. 7. С. 163-169.

13.Полупан Ю. П. Методи визначення ступеня генотипової консолідації селекційних груп тварин. Методики наукових досліджень із селекції, генетики та біотехнології у тваринництві. К. : Аграр. наука. 2005. С. 52-61.

14.Кондратьева Т. Н. Влияние генетических и средовых факторов на продуктивные и экстерьерные признаки айширского скота: автореф. дис. ... канд. с. х. наук. СПб., 2002. 22 с.

15.Лефрлер Т. Ф., Багаев В. В. Характеристика экстерьера методом промеров и индексов телосложения. Вестник Красноярского государственного агроуниверситета. 2014. Вып. 9. С. 142-146.

16. Хмельничий Л. М., Вечорка В. В. Сполучена мінливість промірів та індексів будови тіла з надоєм корів української чорно-рябої молочної породи. Розведення і генетика тварин. № 50. 2015. С. 96-102.

17.Хмельничий Л. М. Оцінка екстер'єру тварин в системі селекції молочної худоби : монографія. Суми : Мрія, 2007. Вісник Сумського національного аграрного університету 
260c.

18.Бащенко М. І., Хмельничий Л. М. Морфологічні властивості вим'я молочної худоби. Вісник Черкаського інституту агропромислового виробництва. Вип. 4. 2004. С. 21-32.

19.Пелехатий М. С., Піддубна Л. М., Кучер Д. М., Кочук-Ященко О. А. Масо-метричні параметри тулуба корівпервісток голштинської та українських чорно-рябої і червоно-рябої молочних порід в умовах молочного комплексу. Вісник Сумського нац. аграр. ун-ту. Наук. журнал. Серія «Тваринництво». Суми. 2016. Вип. 7 (30). С. 82-88.

20.Піддубна Л. М. Ефективність використання генофонду голштинської породи при формуванні регіональної популяції чорно-рябої молочної породи 3б. наук. Пр.. Подільського держ. аграр.-техн. ун-ту. 2010. Вип. 18. С.151-154.

21.Полупан Ю. П. Онтогенетичні та селекційні закономірності формування господарськи корисних ознак молочної худоби : дис. ... доктора с.-г. наук. : 06.02.01. Ін-т розведення і генетики тварин НААН. с. Чубинське Київської обл., 2013. 694 с.

22.Пелехатий М. С., Ковальчук Т. І. Молочна продуктивність та відтворна здатність корів українських новостворених молочних порід різних генотипів. Вісник Державного агроекологічного університету. Житомир. 2005. № 2. С. 184-191.

23.Гончар О. Ф., Сотніченко Ю. М. Селекційні аспекти формування відтворної здатності у корів молочних порід. Розведення і генетика тварин. 2015. Вип. 50. С. 200-207 .

24.Гончарук М. С. Аналіз порушення відтворення у стаді молочної худоби. Розведення і генетика тварин. 2018. Вип. 55. C. $179-186$.

25.Козирь В., Мовчан Т. Підвищення надоїв може погіршити відтворення. Тваринництво України. 2010. № 10. С. $16-$ 19.

26.Підпала, Т., Цхвітава О., Ясєвін С. Відтворення великої рогатої худоби за безприв'язного утримання. Тваринництво України. 2011. № 7. С. 10-12.

\section{References:}

1. Petrenko, I. P., Yefimenko, S. T., Mokhnachova, O. I. and Tsapko V. A., 2011. Molochna produktyvnist symentalskykh pervistok zalezhno vid eksteriernykh typiv ta indeksiv [Dairy productivity of Simmental firstborns depending on exterior types and indices]. Rozvedennia i henetyka tvaryn, no 45, pp. 199-206.

2. Honcharenko, I. V., 2007. Selektsiini indeksy u systemi selektsii molochnykh koriv [Breeding indices in the system of selection of dairy cows]. K.: Ahrarna nauka.

3. Bodnar, P. V. and Bodnar, M. R., 2015. Vykorystannia selektsiinykh indeksiv za kompleksom fenotypovykh oznak u selektsii molochnoi khudoby ta dyferentsiatsii za hospodarskym pryznachenniam [The use of selection indices for a set of phenotypic traits in the selection of dairy cattle and differentiation by economic purpose]. Biolohiia tvaryn, T. 17, no 4. pp. 163.

4. Honcharenko, I. V., 2010. Systema informatsiinoho zabezpechennia i pryskorennia selektsiinoho protsesu v molochnomu skotarstvi [System of information support and acceleration of selection process in dairy cattle breeding]. Zbirnyk naukovykh prats VNAU, no 5 (45), pp. 21-24.

5. Shablia,V. and Synytska O., 2010. Selektsiinyi indeks pozhyttievoho prybutku pleminnykh buhaiv molochnykh porid [Selection index of life expectancy of pedigree bulls of dairy breeds]. Tvarynnytstvo Ukrainy, no 3-4, pp. 36-40.

6. Ruban, S. Yu., Kostenko, O. I., Danshyn, V. O. and Bakadorov, P. P., 2009. Metodolohiia otsinky zmin u populiatsiiakh molochnoi khudoby yak zasib vyznachennia stratehii yikh selektsiinoho udoskonalennia [Methodology for assessing changes in dairy cattle populations as a means of determining the strategy of their selection improvement]. Naukovyi visnyk NUBiP Ukrainy, no 138, pp. 39-47.

7. Ferguson, G., 2002. Don't blame high milk production. Western Dairy Business, no 2. P. 23-25.

8. Babik, N. P., 2017. Tryvalist ta efektyvnist dovichnoho vykorystannia koriv holshtynskoi porody zalezhno vid selektsiinykh indeksiv yikh predkiv [Duration and efficiency of lifelong use of Holstein cows depending on the breeding indices of their ancestors]. Visnyk Sumskoho natsionalnoho ahrarnoho universytetu, issue 5/1 (31), pp. 16-21.

9. Pelekhatyi, M. S. and Kochuk-Yashchenko, O. A., 2019. Molochna produktyvnist ta eksteriernyi typ koriv-pervistok ukrainskoi chorno-riaboi molochnoi porody zalezhno vid vymia-maso-metrychnoho indeksu [Dairy productivity and exterior type of first-born cows of the Ukrainian black-spotted dairy breed depending on the udder-mass-metric index]. Rozvedennia i henetyka tvaryn. Kyiv, issue 57, pp. 102-110.

10. Pelekhatyi, M. S., Piddubna, L. M., Kucher, D. M. and Kochuk-Yashchenko, O. A., 2018. Efektyvnist vykorystannia nepriamoho vidboru molochnykh koriv za maso-metrychnymy parametramy [Efficiency of using indirect selection of dairy cows by mass-metric parameters]. Ahropromyslove vyrobnytstvo Polissia, issue 11, pp. 96-100.

11. Polkovnikova, A. P., Frolov, M. M. and Maltsev A. S., 1987. Metodicheskie rekomendatsii po upravleniyu selektsionnyim protsessom v stadah i porodnom massive krupnogo rogatogo skota [Methodological recommendations for the management of the selection process in herds and breed mass of cattle]. H. : NIIZh Lesostepi i Polesya USSR.

12. Petrenko, I. P. and Polupan, Yu. P., 2003. Prohnozuvannia produktyvnosti molochnykh koriv [Forecasting the productivity of dairy cows]. Visnyk Sumskoho natsionalnoho ahrarnoho universytetu. Seriia «Tvarynnytstvo», issue 7, pp. 163-169.

13. Polupan, Yu. P., 2005. Metody vyznachennia stupenia henotypovoi konsolidatsii selektsiinykh hrup tvaryn [Methods for determining the degree of genotypic consolidation of breeding groups of animals]. Metodyky naukovykh doslidzhen iz selektsii, henetyky ta biotekhnolohii u tvarynnytstvi. K. : Ahrar. nauka, pp. 52-61.

14. Kondrateva, T. N., 2002. Vlyianye henetycheskykh y sredovyikh faktorov na produktyvnyie y eksterernyie pryznaky aishyrskoho skota [The influence of genetic and environmental factors on the productive and exterior traits of Ayshir cattle]: avtoref. dys. ... kand. s. kh. nauk, SPb.

15. Lefler, T. F. and Bagaev, V. V., 2014. Harakteristika eksterera metodom promerov i indeksov teloslozheniya. Vestnik 
Krasnoyarskogo gosudarstvennogo agrouniversiteta [Characteristics of the exterior by the method of measurements and body build indices]. issue 9, pp. 142-146.

16. Khmelnychyi, L. M., and Vechorka, V. V., 2015. Spoluchena minlyvist promiriv ta indeksiv budovy tila z nadoiem koriv ukrainskoi chorno-riaboi molochnoi porody [Combined variability of measurements and body structure indices with milking of cows of the Ukrainian black-spotted dairy breed].. Rozvedennia i henetyka tvaryn, issue 50, pp. 96-102.

17. Khmelnychyi, L. M., 2007. Otsinka eksterieru tvaryn v systemi selektsii molochnoi khudoby : monohrafiia [Evaluation of the exterior of animals in the system of selection of dairy cattle: a monograph]. Sumy : Mriia.

18. Bashchenko, M. I. and Khmelnychyi, L. M. Morfolohichni vlastyvosti vymeni molochnoi khudoby [Morphological properties of the udder of dairy cattle]. Visnyk Cherkaskoho instytutu ahropromyslovoho vyrobnytstva, issue 4, pp. 21-32.

19. Pelekhatyi, M. S., Piddubna, L. M., Kucher, D. M. and Kochuk-Yashchenko O. A., 2016. Maso-metrychni parametry tuluba koriv-pervistok holshtynskoi ta ukrainskykh chorno-riaboi i chervono-riaboi molochnykh porid $v$ umovakh molochnoho kompleksu [Mass-metric parameters of the body of first-born cows of Holstein and Ukrainian black-spotted and red-spotted dairy breeds in the conditions of the dairy complex]. Visnyk Sumskoho nats. ahrar. un-tu. Nauk. zhurnal. Seriia «Tvarynnytstvo». Sumy, issue 7 (30), pp. 82-88.

20. Piddubna, L. M., 2010. Efektyvnist vykorystannia henofondu holshtynskoi porody pry formuvanni rehionalnoi populiatsii chorno-riaboi molochnoi porody [The efficiency of using the gene pool of the Holstein breed in the formation of the regional population of black-spotted dairy breed]. Zb. nauk. Pr.. Podilskoho derzh. ahrar.-tekhn. un-tu, issue 18, pp. 151-154.

21. Polupan Yu. P., 2013. Ontohenetychni ta selektsiini zakonomirnosti formuvannia hospodarsky korysnykh oznak molochnoi khudoby : dys. ... doktora s.-h. nauk. : 06.02 .01 [Ontogenetic and selection patterns of formation of economically useful traits of dairy cattle: dis. ... Doctor of agricultural sciences Science. : 06.02.01].. In-t rozvedennia i henetyky tvaryn NAAN. s. Chubynske Kyivskoi obl.

22. Pelekhatyi M. S. and Kovalchuk T. I., 2005. Molochna produktyvnist ta vidtvorna zdatnist koriv ukrainskykh novostvorenykh molochnykh porid riznykh henotypiv [Dairy productivity and reproductive ability of cows of Ukrainian newly created dairy breeds of different genotypes]. Visnyk Derzhavnoho ahroekolohichnoho universytetu. Zhytomyr, no 2, pp. 184-191.

23. Honchar O. F. and Sotnichenko Yu. M., 2015. Selektsiini aspekty formuvannia vidtvornoi zdatnosti u koriv molochnykh porid [Selection aspects of reproductive ability formation in dairy cows]. Rozvedennia i henetyka tvaryn, issue 50. pp. 200-207 .

24. Honcharuk, M. S., 2018. Analiz porushennia vidtvorennia u stadi molochnoi khudoby. Rozvedennia i henetyka tvaryn [Analysis of reproductive disorders in dairy cattle]. Rozvedennia i henetyka tvaryn, issue 55, pp. 179-186.

25. Kozyr, V. and Movchan, T., 2010. Pidvyshchennia nadoiv mozhe pohirshyty vidtvorennia [Increased milk yield may impair reproduction]. Tvarynnytstvo Ukrainy, no 10, pp. 16-19.

26. Pidpala, T., Tskhvitava, O. and Yasievin S., 2011. Vidtvorennia velykoi rohatoi khudoby za bezpryviaznoho utrymannia [Reproduction of cattle with loose housing]. Tvarynnytstvo Ukrainy, no 7, pp. 10-12.

Kochuk-Yashchenko Oleksandr Anatoliiovych, Ph.D. of Agricultural Sciences

Kucher Dmytro Mykolaiovych, Ph.D. of agricultural sciences

Shapran Inna Valentynivna, Undergraduate

Mosiichuk Mykola Vasylovych, Undergraduate

Polissia National University (Zhytomyr, Ukraine)

The efficiency of index selection in herd of the Simental breed for organic milk production

The article presents the results of selection of Simmental breed cows by udder-mass-metric index, which is a fairly reliable and effective method of determining the best animals by mass-metric parameters of a particular herd. The first-calf cows of the Simmental breed, differentiated by the size of this index, in the vast majority of cases probably differ from each other in these indicators. In general, the size of the animals by the main measurements of body structure in combination with a large live weight within the groups indicates the formation of the milk type of the exterior of the first-calf Simmental cows of the Czech selection PE "GalexAgro". It has been established that with increasing udder-mass-metric index value of cows observed statistically significant pattern of growth of the vast majority of mass-metric indicators of the exterior, except for live weight and breast girth, where animals with average exterior index values were better. In general, in all indicators of the exterior of animals with medium and high values of this index, statistically significantly superior to peers with low values. Deviation from the milk type towards double productivity was observed by the format index, which is defined as the ratio of the oblique length of the torso to the height at the withers. The value of this index varied within groups from 126.0 to $127.2 \%$. Only this index showed a statistically significant difference in favor of animals with a high value of udder-mass-metric index $(P<0.05)$. With an increase in the value of the external index from $(10,5.) \partial 0$ to $(23,6)$ of cows observed increase in the duration of lactation by 29.8 days, an increase in milk yield for 305 days of lactation by $607 \mathrm{~kg}$, obtained more milk fat and protein - by 21.3 and 21.7 , respectively, which is confirmed by a statistically significant difference between group averages. Mathematically confirmed inverse relationship between the deterioration of reproduction and the growth of the udder-mass-metric index in cows was observed. The best indicators of reproduction were animals with low value, the worst - with high. The greatest influence of the external index was observed on the morphological properties of the udder (16.8\%), and the least - on the reproductive capacity $(1,2)$. In general, the generalized mean strength of the udder-mass-metric index effect on all blocks of the studied features was $6.5 \%$ and in $47 \%$ of the total number of comparisons was probable $(P<0.05-0.001)$.

Key words: Simmental breed, organic production, exterior, body measurements, indices, udder, force of influence.

Дата надходження до редакції: 04.09.2020 р.

Вісник Сумського національного аграрного університету 